\title{
Forest ecosystem climate change impact assessment and adaptation strategies for Pakistan
}

\author{
K. M. Siddiqui ${ }^{1, *}$, Iqbal Mohammad ${ }^{2}$, Mohammad Ayaz ${ }^{2}$ \\ ${ }^{1}$ H ouse N o. 454B, Street 11, F-10/2, Islamabad 44000, Pakistan \\ ${ }^{2}$ Pakistan Forest Institute, Peshawar 25120, Pakistan
}

\begin{abstract}
A study was carried out to determine the impact of climate change on natural forest ecosystems in Pakistan assuming a $0.3^{\circ} \mathrm{C}$ rise in temperature and a precipitation change of $0,+1$ and $-1 \%$ decade ${ }^{-1}$ with 1990 as the base year. The current atmospheric $\mathrm{CO}_{2}$ concentration of 350 ppmv was assumed to increase to 425 ppmv in 2020, 500 ppmv in 2050 and 575 ppmv in 2080. The BIOME3 model was used for computer simulation of 9 dominant plant types, or biomes. Of these, 3 biomes (alpine tundra, grassland/arid woodlands and deserts) showed a reduction in their area, and 5 biomes (cold conifer/mixed woodland, cold conifer/mixed forests, temperate conifer/mixed forests, warm conifer/ mixed forests, and steppe/arid shrub lands) showed an increase in their area as a result of climate change. Enhanced $\mathrm{CO}_{2}$ concentration in the atmosphere appeared to have a pronounced effect on the biomes' area. Net primary productivity exhibited an increase in all biomes and scenarios. However, there is a possibility of forest dieback occurring and of time lag before the dominant plant types have enough time to adjust to changed climate and migrate to new sites. In the intervening period, they would be vulnerable to environmental and socio-economic disturbances (e.g. erosion, deforestation, and land-use changes). Thus, the overall impact of climate change on the forest ecosystems of Pakistan could be negative. A number of adaptation strategies are proposed to cope with climate change impacts on forest ecosystems.
\end{abstract}

KEY WORDS: Biome · Forest · Ecosystem · Climate change - Dominant plant type · Net primary productivity · Adaptation

\section{INTRODUCTION}

According to the land use data of the Pakistan Forestry Sector Plan of 1992, natural forests and manmade tree plantations cover 4.224 million ha, or $4.8 \%$ of the land area in the country (Anonymous 1992, Amjad et al. 1996). Agriculture, both irrigated and non-irrigated, is practiced on 20.58 million ha, or $23.4 \%$ of the land area, and livestock grazing on 28.509 million ha, or $32.4 \%$ of the area. The balance of 34.67 million ha, or $39.4 \%$, consists of snow, glaciers, rock, deserts, tidal flats, water bodies, river beds, lakes, dams, towns, cities, and so forth. The non-productive use of most of the land area is due to the arid climate, with less than $250 \mathrm{~mm}$ of annual rainfall over

*E-mail: khalid_m@geocities.com more than $70 \%$ of the country. Forest area is also small and scattered for the same reason, as natural tree growth is not possible in low-rainfall areas (Siddiqui 1997). Further, not all of the forested area has dense tree cover. Rather, $93 \%$ of coniferous forests, $34 \%$ of riverine forests, $58 \%$ of mangrove forests, and $46 \%$ of irrigated plantations have low-density tree growth (Anonymous 1992). Pakistan nonetheless has a rich and diversified flora because of the wide variety of soils, topography, and climatic conditions.

The natural forests in Pakistan have been subjected to deforestation for growing agricultural crops, grazing domestic animals, and obtaining fuel wood and timber over a period of thousands of years. The coniferous forests in the northern mountain regions particularly are under the heavy social and economic pressure of tree felling (Schickoff 1993, Knudson 1994). The ecological, socio-economic, commercial, environmental, 
and climatic importance of these forests is considerable. They supply coniferous timber, fuel wood, minor forest produce, hydroelectric power, drinking and irrigation water, minerals, soil nutrients, and places for tourism and recreation. The mountain regions are important centers of biodiversity. Their glaciers, flora, and fauna are indicators of climate change. The altitudinal pattern of vegetation in northern regions of Pakistan follows the latitudinal pattern of vegetation found globally. In the future, these forests are expected to face the combined effect of climate change and socio-economic demands for forest products and services. The distribution of Pakistan's forests is given in Fig. 1.

This paper describes the results of a study to determine the impact of climate change on natural ecosystems in Pakistan in general and forest ecosystems in northern parts of the country in particular in order to suggest adaptation strategies that could be adopted by policy makers to cope with this change. The expected changes in distribution of different forest ecosystems, as well as in their parameters of growth, were determined for the years 2020, 2050 and 2080 taking $30 \mathrm{yr}$ average climate data for the period $1961-90$ as the baseline and assuming a $0.3^{\circ} \mathrm{C}$ rise in temperature and a $0,+1$ and $-1 \%$ change in precipitation per decade, with 1990 as the base year. In addition, the current atmospheric $\mathrm{CO}_{2}$ concentration of 350 ppmv is expected to increase to 425 ppmv in 2020, 500 ppmv in 2050, and 575 ppmv in 2080 in this study.

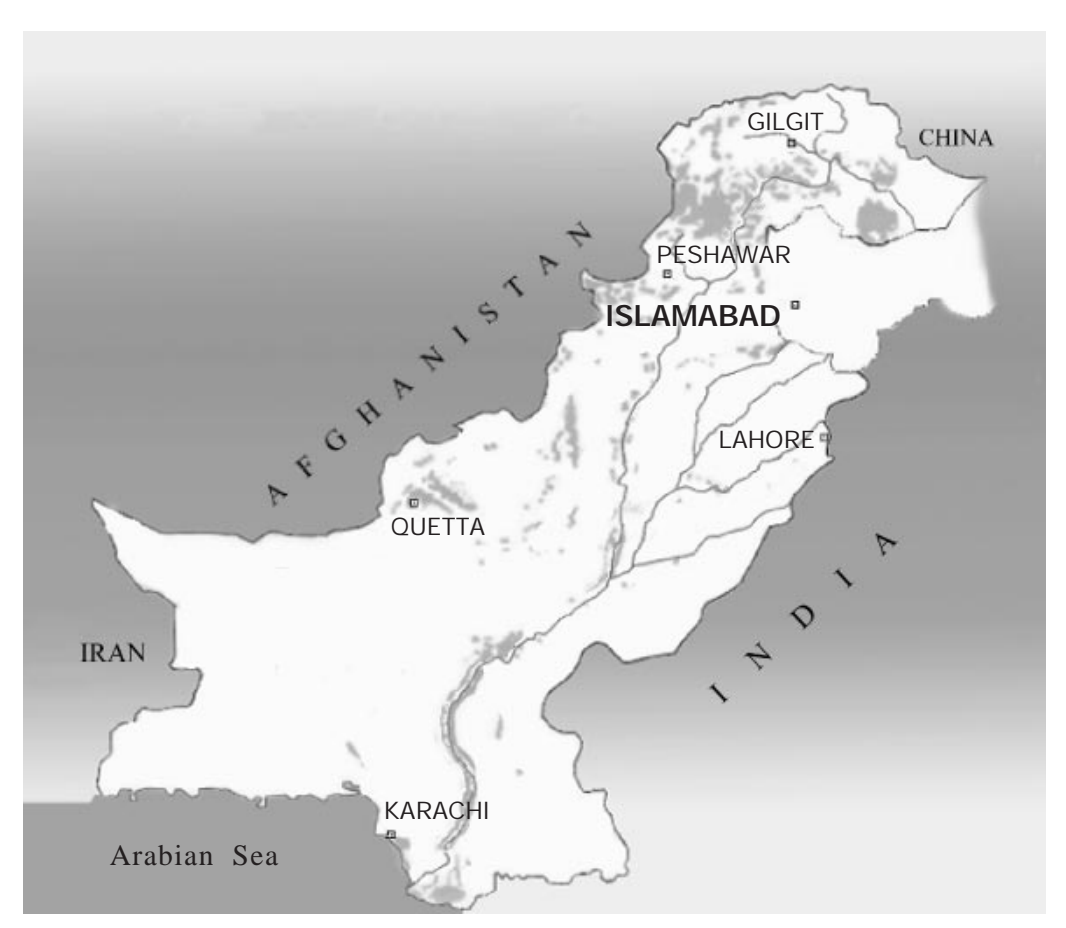

Fig. 1. Distribution of Pakistan's forests

\section{STUDY AREA}

The forests in mountainous regions of Pakistan are the focus of this study. These regions occupy 11.534 million ha, which is $13.1 \%$ of total area of this country which supports about 8.45 million people, or $6.5 \%$ of the country's total human population. In general, the altitude of this region varies from less than $1000 \mathrm{~m}$ to more than $8000 \mathrm{~m}$. The mountain system comprises the Karakoram, the great Himalayas, and the Hindukush. The timberline, or elevation limit of tree growth, is exceptionally high in these mountains, rising from $3000 \mathrm{~m}$ in the lesser Himalayas to $4000 \mathrm{~m}$ above sea level in the area of higher inner mountains, compared with $2000 \mathrm{~m}$ usually observed in tropical or temperate mountains. High summer rainfall occurs where high mountain masses stand exposed to the moist southwest winds. Tracts to the leeward side are invariably dry (for example, the inner valleys). Snow is received in winter in high mountain reaches, which is a source of river water in the plains in early summer. Two types of natural forests are found in the mountains: scrub forests (xerophytic forests of thorny and small-leaved evergreen species) up to 1000 to $1200 \mathrm{~m}$ elevation and coniferous forests, pure and mixed with hardwood species, from $1200 \mathrm{~m}$ elevation to the tree limit. Together, these forests cover approximately $3.1 \mathrm{mil}-$ lion ha (Amjad et al. 1996).

\section{SELECTION OF MODEL}

Two (sometimes considered 3) approaches and 4 levels/scales are used for mathematical modeling of forest vegetation response to climate change, and several hundred such models have been reported in the literature (Prentice et al. 1992, Gates 1993, Miellilo et al. 1993, Nielson 1995). Of these, the BIOME3 model developed by Haxeltine (1996), was selected for this study because it gives an integrated analysis of the impacts of climate change and $\mathrm{CO}_{2}$ on ecosystem structure and function. It is based on ecological constraints (cold tolerance and seasonality requirement), resource availability (water, nutrients, $\mathrm{CO}_{2}$, and light), and the effect of competition among plant functional types on vegetation structure. It mechanistically models the performance of different plant types with change in climate and in $\mathrm{CO}_{2}$ concen- 
tration. Model inputs consist of latitude, soil texture class, and monthly climate (temperature, precipitation and sunshine) data on a $0.5^{\circ}$ grid. Temperature data were extrapolated to the mean elevation of each cell (10' grid), assuming an environmental lapse of $0.6^{\circ} \mathrm{C}$ per $100 \mathrm{~m}$ elevation. The actual climatological data for 45 (average for 1960-90 period) and 31 meteorological stations in Pakistan were used to run the model (Khan 1988). Simulations were also carried out with BIOME3 for a set of 12 forest sites and 2 non-forest sites in Pakistan for verification of the model results. Model outputs consisted of a quantitative vegetation state description in terms of dominant plant types, secondary plant types present, and total leaf area index and net primary productivity (NPP), as well as large-scale vegetation patterns.

\section{VEGETATION TYPES AND BIOMES}

Ecologically, 9 broad forest types are found in Pakistan (Champion et al. 1965). A similar number of biomes, or dominant plant types, were simulated in this study by the BIOME3 model to provide an indication of potential vegetation instead of actual vegetation in the country. They are briefly described below.

4.1. Alpine tundra. This biome is predicted in humid areas that have abundant precipitation (meeting more than $65 \%$ of moisture demand) but an insufficient number $(<350)$ of growing degree days (GDDs) to support tree growth. It covers fairly flat ground at an altitude of more than $3660 \mathrm{~m}$, which is covered by snow for 5 to 6 mo in a year. Naturally occurring grasses in these alpine pastures or meadows are Festuca, Poa, Lolium, Eragrostis, Danthonia, and Phleum, as well as many forbes, such as Primula, Aremons, Fritillaria, and Gentiana sp. The grasses and forbes are highly nutritious and are extensively and heavily grazed during summer months by herds of goats, sheep, and horses and are thus being degraded at a fast rate. Wooded tundra also has subalpine mixed forests of Salix, Lonicera, Berberis, Conoteaster, J uniperus, Rhododendron, and Ephedra.

4.2. Cold conifer/M ixed woodland. This biome contains both the boreal conifer forest/woodland and the boreal deciduous forest/woodland biomes of Prentice et al. (1992) that are dominated by cool temperate conifers Abies spectablis, Pinus wallichiana, and J uniperus recurva, and evergreen broad-leaved trees Betula utilis, Salix, Vibernum, and Rhododendron anthopogen as sporadic single trees, in groups, or in irregular dense stands. They have a humid maritime climate with winter temperature of -2 to $-15^{\circ} \mathrm{C}$ or even colder $\left(>-60^{\circ} \mathrm{C}\right)$ with too little precipitation ( $<75 \%$ of demand) and 350 to 1200 GDDs.
4.3. Cold conifer/Mixed forest. This biome also corresponds to the subalpine forest type and consists of dense forests with species composition, characteristics, and occurrence which are the same as for the cold conifer/mixed woodland biome (see Section 4.2 above). The trees have a moderate rate of growth in this biome.

4.4. Temperate conifer/Mixed forest. These are extensive coniferous forests that are similar to north temperate forests in Europe and North America, having commonly more or less pure crops of 2 species and the mixtures of blue pine Pinus wallichiana and Deodar Cedrus deodara. Winter temperatures are $>-4^{\circ} \mathrm{C}$ with 1200 GDDs within an altitudnal range of 1800 to $3660 \mathrm{~m}$ on moderate to steep slopes. Other species are fir A bies spectabilis, spruce Picea smithiana, Pinus geradiana, J uniperus excelsa, Quercus dilatata, Q. semicarpifolia, Populus ciliata, and Aesculus indica. The wood of all species is highly valued as timber. In addition, medicinal plants, mushrooms, and fodder are collected in the forests.

4.5. Warm conifer/M ixed forest. This biome is dominated mostly by warm temperature evergreen conifer trees of chir pine Pinus roxburghii in regions with mean coldest month temperatures of 5 to $15^{\circ} \mathrm{C}$ and with rainfall sufficient to meet more than $65 \%$ of the moisture requirement between 1000 and 1800 m elevation.

4.6. Xerophytic wood/Scrub. These are low forests of branchy, thorny, evergreen trees, and shrubs. Their major climatic descriptor is a long dry season tempered in more northerly parts by winter and spring precipitation and to the south by a summer monsoon of variable incidence. The dominant species are Olea ferugiea, Acacia modesta, and Dedonaea viscosa.

4.7. G rassland/Arid woodland. This biome consists of tropical plains and has Prosopis cineraria, Salvadora oleoides, Acacia senegal, Calligonum polygonoides, Zizyphus mauritiana, and Tamarix troupi along with a number of grasses, such as Eulaliopsis binata, Themedia anathera, Cenchrus celliaris, and so forth.

4.8. Steppe/A rid shrubland. This biome is somewhat similar to the xerophytic wood/scrub biome (see Section 4.6 above). Olea ferugniea, Pistacia spp., Fraxinus zanthoxyloides, Dephne mucronata, Astragalus stockii, Helliotropium sp., and Artemisia spp. are found in it.

4.9. Desert. This is the largest type and covers most of the Indus plain, including the major deserts of Thar, Thal, and Cholistan; in total, over 11 million ha in Pakistan. Rainfall is less than $500 \mathrm{~mm}$. These deserts have been converted into agricultural land and 103000 ha tree plantations wherever irrigation water is available. Riverine forests receiving floodwater cover 173000 ha, and mangroves along the sea coast cover 207000 ha. The rest of the area is used for grazing. Scattered trees and shrubs are found in it. It is similar in plant composition to the grassland/arid woodland biome (see Section 4.7 above). 
Table 1. Areas $\left(\times 10^{6}\right.$ ha) simulated for different biomes under current and changed climates. Current: based on average yearly climatic data for the period 1961-90. Changed: based on the assumption that there will be an overall change of $-3,0$, and $+3 \%$ in precipitation $(P)$ coupled with a $0.9^{\circ} \mathrm{C}$ increase in temperature in $2020, a-6,0$, and $+6 \%$ change in precipitation and $1.8^{\circ} \mathrm{C}$ increase in temperature in 2050, and a $-9,0$, and $+9 \%$ change in precipitation and a $2.7^{\circ} \mathrm{C}$ increase in temperature in 2080

\begin{tabular}{|c|c|c|c|c|c|c|c|c|c|c|}
\hline \multirow[t]{2}{*}{ Biome type } & \multirow{2}{*}{$\begin{array}{l}\text { Current } \\
\text { (1961-90) }\end{array}$} & \multicolumn{3}{|c|}{2020} & \multicolumn{3}{|c|}{2050} & \multicolumn{3}{|c|}{2080} \\
\hline & & $-P$ & $\mathrm{OP}$ & $+P$ & $-P$ & $\mathrm{OP}$ & tP & $-P$ & $\mathrm{OP}$ & $+P$ \\
\hline Alpine tundra & 5.9 & 4.9 & 4.9 & 4.0 & 4.0 & 4.0 & 3.6 & 3.6 & 3.6 & 3.6 \\
\hline Cold conifer/M ixed woodland & 1.0 & 1.2 & 1.2 & 1.1 & 1.5 & 1.4 & 1.2 & 1.4 & 1.3 & 1.1 \\
\hline Cold conifer/M ixed forest & 3.1 & 3.5 & 3.5 & 3.6 & 3.6 & 3.8 & 3.9 & 3.3 & 3.5 & 3.6 \\
\hline Temperate conifer/M ixed forest & 3.8 & 4.1 & 4.1 & 4.1 & 4.0 & 4.1 & 4.1 & 4.5 & 4.6 & 4.6 \\
\hline Warm conifer/M ixed forest & 4.3 & 5.4 & 5.9 & 5.9 & 6.4 & 6.9 & 7.2 & 6.7 & 7.4 & 8.2 \\
\hline Xerophytic wood/Shrub & 6.0 & 6.0 & 5.8 & 6.0 & 5.9 & 5.8 & 5.9 & 6.0 & 6.0 & 6.0 \\
\hline Grassland/Arid woodland & 0.7 & 0.4 & 0.5 & 0.5 & 0.3 & 0.3 & 0.3 & 0.3 & 0.3 & 0.4 \\
\hline Steppe/Arid shrubland & 33.3 & 34.9 & 35.8 & 36.7 & 36.1 & 37.4 & 39.0 & 36.5 & 38.7 & 39.9 \\
\hline Desert & 28.6 & 26.3 & 25.0 & 23.8 & 24.8 & 23.0 & 21.0 & 24.4 & 21.3 & 19.1 \\
\hline Total & 86.7 & 86.7 & 86.8 & 86.7 & 86.7 & 86.8 & 86.7 & 86.8 & 86.8 & 86.5 \\
\hline
\end{tabular}

\section{ASSE SSMENT OF IM PACT}

NPP is the rate at which an ecosystem fixes carbon by photosynthesis from the atmosphere (gross primary productivity) minus the rate at which it returns carbon to the atmosphere by respiration. A model simulation for 2020, 2050, and 2080 with increased $\mathrm{CO}_{2}$ concentration in the atmosphere showed an increase in NPP of coniferous forests to the extent of $755 \mathrm{~g} \mathrm{C} \mathrm{m}^{-2} \mathrm{yr}^{-1}$. This may be due to a large increase in photosynthetic rates through a fertilization effect and/or a reduction in transpiration rate and plant water requirement that is directly reflected in increased NPP or aboveground productivity (Norby et al. 1986, Curtis et al. 1989). In actual practice, however, this increase may not occur due to limited soil nutrient availability and may, therefore, be regarded as the upper limit on the likely increases in NPP of chir pine and blue pine.

On the other hand, increased temperature alone or in combination with increased $\mathrm{CO}_{2}$ concentration in general results in northward and upward movement of cold and temperate conifer forests in Pakistan. Further, as increased $\mathrm{CO}_{2}$ concentration also allows plants to cope better with arid conditions, this results in southward expansion of warm conifer forests into areas occupied by dry forests. The model predicts this change even in the absence of an increase in precipitation. The net result of these changes is large increases in the potential area of warm conifer forests due to the combined effects of increased $\mathrm{CO}_{2}$ and temperature, with much smaller increases in the area covered by the temperate and cold conifer biomes. The first-order effects of an increase in temperature could be the timberline moving up the mountain slopes, disappearance of alpine grasslands in those areas where mountaintops are just above the timberline, and changes in plant composition, cover, and location. An increase in forested area in Pakistan is also expected with an increase in precipitation, as forests would move into arid areas. Areas of different biomes under current and changed climates simulated with the help of the model are given in Table 1, and potential vegetation for 2050 is shown in Fig. 2. The percentage changes in areas of different biomes under changed climate conditions are given in Table 2.

Table 2. Percentage changes in areas of different biomes under changed climate

\begin{tabular}{|c|c|c|c|c|c|c|c|c|c|}
\hline \multirow[t]{2}{*}{ Biome type } & \multicolumn{3}{|c|}{2020} & \multicolumn{3}{|c|}{2050} & \multicolumn{3}{|c|}{2080} \\
\hline & $-P$ & $\mathrm{OP}$ & $+P$ & $-P$ & $\mathrm{OP}$ & $+P$ & $-P$ & $\mathrm{OP}$ & $+P$ \\
\hline Alpine tundra & -16.7 & -16.7 & -16.7 & -31.5 & -31.5 & -31.5 & -38.9 & -38.9 & -38.9 \\
\hline Cold conifer/M ixed woodland & 22.2 & 22.2 & 11.1 & 5.6 & 44.4 & 22.2 & 44.4 & 33.3 & 11.1 \\
\hline Cold conifer/M ixed forest & 10.3 & 10.3 & 13.8 & 13.8 & 20.7 & 24.1 & 6.9 & 10.3 & 13.8 \\
\hline Temperate conifer/M ixed forest & 5.6 & 5.6 & 5.6 & 2.8 & 5.6 & 5.6 & 16.7 & 19.4 & 19.4 \\
\hline Warm conifer/M ixed forest & 22.0 & 22.0 & 34.1 & 43.9 & 56.1 & 63.4 & 51.2 & 68.3 & 85.4 \\
\hline Xerophytic wood/Scrub & 0.0 & 0.0 & 0.0 & -1.8 & -3.6 & -1.8 & 0.0 & 0.0 & 0.0 \\
\hline Grassland/Arid woodland & -42.9 & -28.6 & -28.6 & -57.1 & -57.1 & -57.1 & -57.1 & -57.1 & -28.6 \\
\hline Steppe/Arid shrubland & 5.2 & 8.1 & 10.7 & 9.1 & 13.0 & 17.6 & 10.1 & 16.9 & 20.5 \\
\hline Desert & -7.6 & -7.6 & -16.3 & -12.9 & -19.3 & -26.1 & -14.4 & -25.4 & -33.0 \\
\hline
\end{tabular}




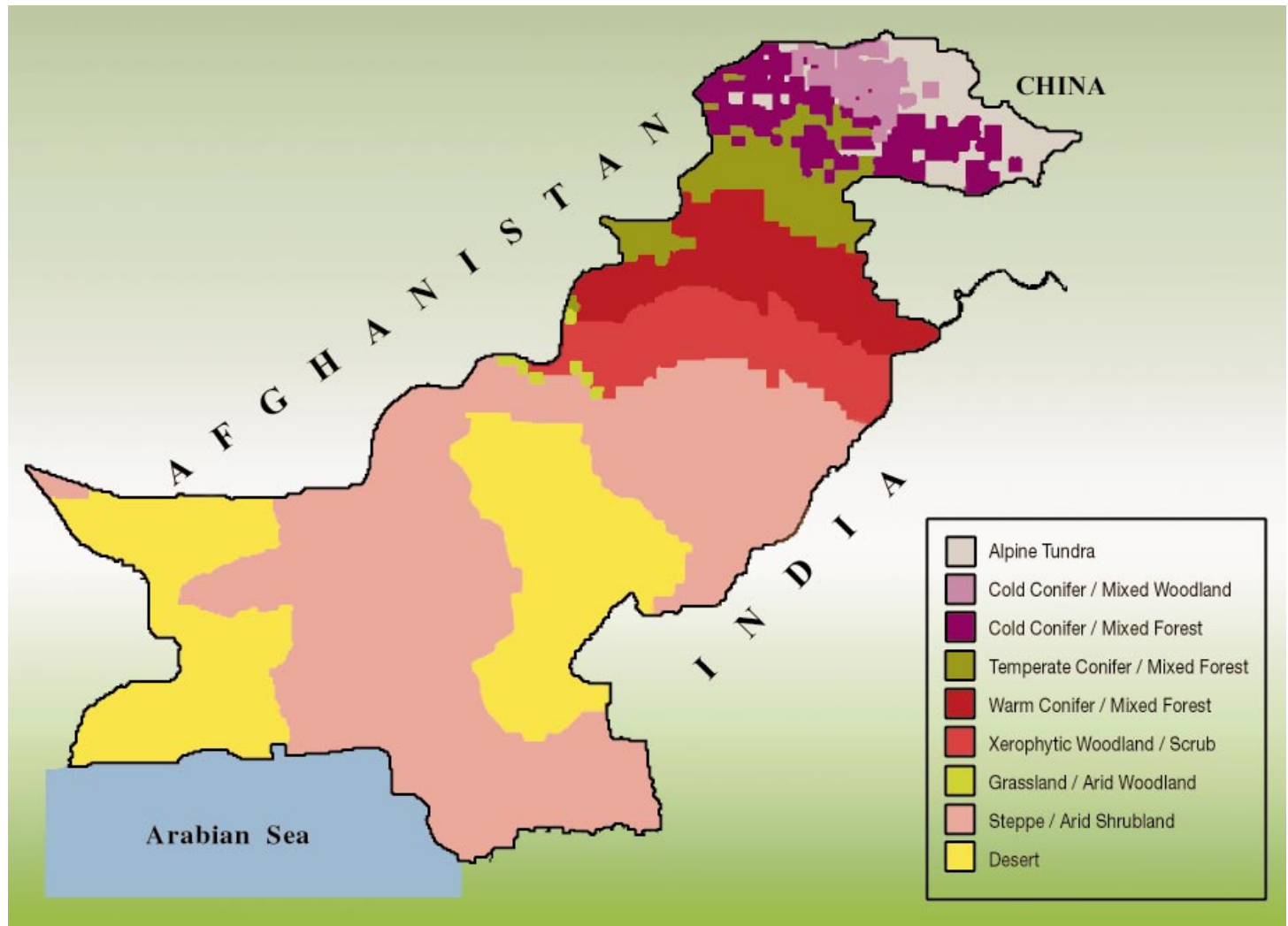

Fig. 2. Potential vegetation of Pakistan (2050)

\subsection{Simulated changes in N PP}

Table 3 shows an increase in average model-simulated NPP for different biomes due to an increase in precipitation, temperature, and atmospheric $\mathrm{CO}_{2}$ concentration. However, NPP of some biomes slightly decreases with the increase in precipitation if the biome moves to less productive areas with changed climate (for example, cold conifer/mixed woodland biome from 184 down to $177 \mathrm{~g} \mathrm{C} \mathrm{m}^{-2} \mathrm{yr}^{-1}$ in 2050 and from 196 down to $191 \mathrm{~g} \mathrm{C} \mathrm{m}^{-2} \mathrm{yr}^{-1}$ in 2080). This is because, as the precipitation increases, areas occupied by woodlands are able to produce a more closed canopy with a higher leaf area. They are then classified as forests, while the woodlands are left only in the really dry area where the precipitation increase is too low to make any difference. The fact that they compose a greater fraction of the remaining area under the changed climate results in a decrease in the average NPP per unit area for this biome.

Table 3. Average net primary productivity (NPP; $\mathrm{g} \mathrm{C} \mathrm{m}^{-2} \mathrm{yr}^{-1} / \mathrm{tC} \mathrm{km}^{-2} \mathrm{yr}^{-1}$ ) for different biomes under present and changed climate

\begin{tabular}{|c|c|c|c|c|c|c|c|c|c|c|}
\hline \multirow[t]{2}{*}{ Biome type } & \multirow{2}{*}{$\begin{array}{l}\text { Current } \\
\text { (1961-90) }\end{array}$} & \multicolumn{3}{|c|}{2020} & \multicolumn{3}{|c|}{2050} & \multicolumn{3}{|c|}{2080} \\
\hline & & $-P$ & $\mathrm{OP}$ & $H$ & $-P$ & $\mathrm{OP}$ & 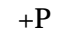 & $-P$ & $\mathrm{OP}$ & $+P$ \\
\hline Alpine tundra & 94 & 103 & 104 & 104 & 115 & 117 & 118 & 130 & 133 & 136 \\
\hline Cold conifer/M ixed woodland & 161 & 176 & 178 & 176 & 184 & 180 & 177 & 196 & 197 & 191 \\
\hline Cold conifer/Mixed forest & 331 & 354 & 355 & 353 & 380 & 381 & 381 & 394 & 400 & 402 \\
\hline Temperate conifer/M ixed forest & 639 & 722 & 728 & 735 & 784 & 797 & 803 & 819 & 829 & 845 \\
\hline Warm conifer/M ixed forest & 653 & 761 & 763 & 776 & 857 & 876 & 898 & 939 & 972 & 1000 \\
\hline Xerophytic woods/Scrub & 393 & 443 & 434 & 439 & 482 & 482 & 488 & 520 & 524 & 521 \\
\hline Grassland/Arid woodland & 322 & 341 & 319 & 321 & 367 & 348 & 364 & 352 & 342 & 335 \\
\hline Steppe/Arid shrubland & 139 & 163 & 165 & 167 & 182 & 189 & 195 & 199 & 210 & 221 \\
\hline Desert & 61 & 70 & 70 & 70 & 77 & 78 & 79 & 84 & 85 & 89 \\
\hline
\end{tabular}


Table 4 also shows variable increases (percent) in the NPP of all forest biomes with change in climate. However, compared with other biomes, the warm conifers exhibit a continuous upward trend from an increase of $16.4 \%$ for decreased precipitation in 2020 to a more than $50 \%$ increase in NPP in 2080 . Thus these forests will become denser and have a closer canopy in 2080 if not disturbed by the human hand.

From the results, it is apparent that impacts of a changing climate on the coniferous forests of northern Pakistan include (1) an increase in area, (2) an increase in productivity, and (3) changes in species composition. The total area of 3 main coniferous forest biomes (cold, temperate, and warm conifer) increases under all climate change scenarios. The model predicts an increase of about one-third in the potential coniferous forest area, with a simultaneous $22 \%$ increase in its average NPP by the year 2050. Similarly, the coniferous forest area increases by $43 \%$ and its NPP by $38 \%$ by 2080 . The actual change in forest area would, however, depend mostly upon the ability of the species to migrate to new areas as well as on the activities of human beings in the forested areas.

The simulations also indicate how the optimal tree species in different biomes might change with climate change as well as how areas that are currently not suitable for forestry might become so as the climate changes. A bout half of the area where the natural vegetation is currently cold conifer would change to a new dominant vegetation type-mostly to the temperate coniferous biome. In terms of actual changes in species composition, this would mean that in many areas where fir and spruce are currently dominant, the more temperate coniferous species such as deodar and blue pine would become dominant. Further, about $18 \%$ of the area occupied by temperate coniferous trees would be replaced by warm coniferous trees and chir pine would move into areas currently occupied by fir, blue pine and deodar, thus adding to its extent without acceding any ground to any other biome, up or down.
Almost three-fourths of the area currently occupied by grassland/arid woodland would change to a new biome of higher order.

\subsection{N PP for some selected forest and non-forest sites}

Twelve growth sample plots established by the Pakistan Forest Institute in areas with different forest types and in 2 non-forest areas - one at a very high altitude and the other on the plains-were selected to determine their NPP under present and changed climates. There were 3 plots each for fir, deodar, blue pine, and chir pine. They also represented 3 elevational levels of natural occurrence of these species-that is, low, medium, and high. Results for the baseline period and the subsequent $30 \mathrm{yr}$ intervals were obtained and are given in Table 5. The model findings are an increase of 15 to $25 \%$ for 2020,35 to $40 \%$ for 2050 and 50 to $55 \%$ for 2080 in NPP as a result of climate change in all localities with or without an increase in precipitation. Of the 2 non-forest sites, the Parma site is more or less above the treeline and is comparable to cold coniferous forests. Under changed climate, it does not have a higher NPP value in 2080 than the xerophytic wood/scrub (Table 3). On the other hand, the Lakki site is already xerophytic wood/scrub. A changed climate may enhance its ranking to the order of temperate forests with regard to NPP. Further, increased NPP of all the sites can be attributed to increased temperature coupled with increased concentrations of $\mathrm{CO}_{2}$ in the atmosphere.

\section{SENSITIVITY AN ALYSIS}

The biomes that are at the extreme ends of the spectrum are more sensitive to climate change than others. For example, alpine tundra loses almost $32 \%$ of its space to other biomes, especially to those that are

Table 4. Percentage changes in average NPP of different biomes

\begin{tabular}{|c|c|c|c|c|c|c|c|c|c|}
\hline \multirow[t]{2}{*}{ Biome type } & \multicolumn{3}{|c|}{2020} & \multicolumn{3}{|c|}{2050} & \multicolumn{3}{|c|}{2080} \\
\hline & $-P$ & $\mathrm{OP}$ & $H$ & $-P$ & $\mathrm{OP}$ & $H$ & $-P$ & $\mathrm{OP}$ & $+P$ \\
\hline Alpine tundra & 9.6 & 10.6 & 10.6 & 22.3 & 24.4 & 25.5 & 38.3 & 41.5 & 44.7 \\
\hline Cold conifer/M ixed woodland & 9.3 & 10.6 & 9.3 & 14.3 & 11.8 & 9.9 & 21.7 & 22.4 & 18.4 \\
\hline Cold conifer/M ixed forest & 6.9 & 7.3 & 6.6 & 14.8 & 15.1 & 15.1 & 19.0 & 20.8 & 21.5 \\
\hline Temperate conifer/M ixed forest & 13.1 & 13.9 & 15.0 & 22.7 & 24.7 & 25.6 & 28.2 & 29.8 & 32.3 \\
\hline Warm conifer/M ixed forest & 16.4 & 16.9 & 18.9 & 31.3 & 34.1 & 37.5 & 43.7 & 48.9 & 53.1 \\
\hline Xerophytic wood/Scrub & 12.6 & 10.5 & 11.7 & 22.6 & 22.6 & 24.3 & 32.2 & 33.4 & 32.7 \\
\hline Grassland/Arid woodland & 5.8 & -1.1 & -0.5 & 13.7 & 8.0 & 13.0 & 9.0 & 5.9 & 3.9 \\
\hline Steppe/A rid shrubland & 16.7 & 18.0 & 19.7 & 30.5 & 35.4 & 40.0 & 42.5 & 50.4 & 58.6 \\
\hline Desert & 14.5 & 14.7 & 14.9 & 26.9 & 28.5 & 30.0 & 37.7 & 40.7 & 45.7 \\
\hline
\end{tabular}


Table 5. NPP ( $\left.\mathrm{g} \mathrm{C} \mathrm{m}^{-2} \mathrm{yr}^{-1} / \mathrm{t} \mathrm{C} \mathrm{km}^{-2} \mathrm{yr}^{-1}\right)$ for selected sites/species under current and changed climate

\begin{tabular}{|c|c|c|c|c|c|c|c|c|c|c|c|c|c|c|c|}
\hline \multirow[t]{2}{*}{ Species } & \multirow[t]{2}{*}{ Locality } & \multirow{2}{*}{$\begin{array}{l}\text { Altitude } \\
\text { (m) }\end{array}$} & \multirow{2}{*}{ Latitude } & \multirow{2}{*}{ Soil type } & \multirow{2}{*}{$\begin{array}{l}\text { Soil depth } \\
\text { (cm) }\end{array}$} & \multirow{2}{*}{$\begin{array}{l}\text { Current } \\
(1961-90)\end{array}$} & \multicolumn{3}{|c|}{2020} & \multicolumn{3}{|c|}{2050} & \multicolumn{3}{|c|}{2080} \\
\hline & & & & & & & $-P$ & $\mathrm{OP}$ & $H$ & $-P$ & $\mathrm{OP}$ & $H P$ & $-P$ & $\mathrm{OP}$ & $H$ \\
\hline Fir & Kamal Ban & 2100 & $34^{\circ} 43^{\prime}$ & Rock-shale & 100 & 694 & 827 & 832 & 836 & 946 & 954 & 961 & 1053 & 1065 & 1076 \\
\hline Fir & Malam Jaba & a 3050 & $34^{\circ} 50^{\prime}$ & Sandy-Ioam & 100 & 483 & 569 & 570 & 571 & 650 & 652 & 653 & 726 & 733 & 738 \\
\hline Fir & Donga Gali & 2750 & $34^{\circ} 10^{\prime}$ & Rock-loam & 50 & 500 & 586 & 586 & 586 & 671 & 672 & 673 & 777 & 781 & 783 \\
\hline Deodar & Nuri & 1650 & $34^{\circ} 47^{\prime}$ & Loamy-rock & 60 & 739 & 873 & 879 & 884 & 989 & 1001 & 1011 & 1098 & 1115 & 1130 \\
\hline Deodar & Nadi & 2290 & $34^{\circ} 39^{\prime}$ & Loamy-rock & 80 & 641 & 765 & 769 & 772 & 876 & 883 & 889 & 978 & 990 & 999 \\
\hline Deodar & Behrain & 1650 & $35^{\circ} 15^{\prime}$ & Loamy-rock & 70 & 495 & 592 & 601 & 609 & 678 & 696 & 715 & 753 & 785 & 822 \\
\hline Blue pine & Bazar Kot & 1680 & $34^{\circ} 40^{\prime}$ & Loamy-rock & 90 & 679 & 813 & 822 & 830 & 937 & 955 & 970 & 1042 & 1069 & 1091 \\
\hline Blue pine & Paryai & 1950 & $34^{\circ} 36^{\prime}$ & Loamy-rock & 100 & 717 & 850 & 853 & 857 & 967 & 975 & 981 & 1077 & 1090 & 1100 \\
\hline Blue pine & Patriata & 1981 & $33^{\circ} 50^{\prime}$ & Loam & 100 & 740 & 877 & 882 & 887 & 999 & 1010 & 1019 & 1107 & 1124 & 1140 \\
\hline Chir pine & Sambli & 1370 & $33^{\circ} 40^{\prime}$ & Sandy-loam & 60 & 847 & 992 & 1001 & 1010 & 1111 & 1131 & 1148 & 1210 & 1240 & 1266 \\
\hline Chir pine & Panjar & 850 & $32^{\circ} 30^{\prime}$ & Sandy-rock & 40 & 505 & 600 & 614 & 630 & 677 & 711 & 743 & 739 & 794 & 849 \\
\hline \multirow[t]{3}{*}{ Chir pine } & Charihan & 1950 & $34^{\circ} 00^{\prime}$ & Clayey-loam & 40 & 737 & 871 & 877 & 883 & 991 & 1004 & 1015 & 1097 & 1118 & 1136 \\
\hline & Parma & 4286 & $34^{\circ} 44^{\prime}$ & & & 311 & 370 & 374 & 377 & 431 & 440 & 447 & 493 & 506 & 518 \\
\hline & Lakki & 220 & $32^{\circ} 37^{\prime}$ & & & 485 & 585 & 603 & 621 & 669 & 709 & 750 & 739 & 807 & 872 \\
\hline
\end{tabular}

immediately below (for example, the cold coniferous/ mixed woodland). On the other hand, warm conifers gain large areas when there is an increase in precipitation and temperature. This biome can expand in both north and south directions, which is not the case for other biomes. Grassland/arid woodlands, though very small in area (700000 ha), exhibit tremendous sensitivity to climate changes. They lose about $43 \%$ of their area in 2020, when the precipitation decreases, but actually concede only an area of about $29 \%$ to higher biomes with an increase in precipitation. Deserts are also very sensitive to precipitation changes. An increase in precipitation may cause them to lose as much as $26 \%$ of their area by the year 2050 and $33 \%$ in 2080 to a higher biome.

As far as NPP is concerned, it generally tends to increase in terms of net carbon assimilation per unit area and is thus sensitive to the increased availability of $\mathrm{CO}_{2}$ in the atmosphere. If we look at the individual biomes, particularly the tree biomes, and their response to an increase in the concentration of $\mathrm{CO}_{2}$, we can see that warm conifers gain tremendously: about $38 \%$ in 2050 and $53 \%$ in 2080 for increased precipitation. Grasslands have a very poor response to changing climate. They lose about $1 \%$ during 2020 , but may gain a little afterwards. The extreme biomes-alpine tundra and deserts-are very receptive to climate changes as they both gain between 25 and $30 \%$ in 2050, and about 45\% each in the year 2080.

\section{ADAPTATION STRATEGIES}

The forestry sector is highly sensitive to climate changes as far as its extent, composition, and productivity are concerned. However, forest adjustment dur- ing climate change relies heavily on human adjustment and adaptation. Significant changes in forests may be expected with climate change in the future as described in earlier sections, and adaptation to these changes will become inevitable. This study suggests anticipatory adaptations that are better than waiting for climate change and then reacting to it. Not only may the latter be costly, but the climate change results may be irreversible-for example, loss of biodiversity. Further, anticipatory measures would give benefits even in the absence of climate change and therefore constitute no-regret options. The following adaptation strategies are worth considering in this regard.

(1) Not much attention has been paid so far to selection of suitable tree species for planting in mountain areas. Now, only such species should be selected for planting that, besides being fast growing and providing needed products, are able to adapt to a wide range of future temperature and moisture regimes. Chir pine has already proven its wide adaptability to a wide range of ecological conditions. However, hardy seed sources of blue pine and fir will have to be identified for planting in temperate and cold conifer forests under changed conditions when moisture availability will be low and incidence of fire will be high.

(2) At present, wood is used in a highly wasteful manner both as fuel and construction material. Heating efficiency of country-made open stoves is hardly more than 10 to $15 \%$, and smoke generated as a result of the burning of fuel wood within household premises is injurious to the residents, especially to women who carry out the cooking of food. In many instances, cooking and heating of space in the hilly regions is done with separate stoves. These operations could be combined to increase fuel efficiency, save fuel wood, reduce health hazards, and facilitate a clean living 
environment. Similarly, timber is used in large quantities for construction of flat-roofed mud houses by northern mountain dwellers, even in those areas that receive a substantial quantity of snow in winter. Substantial saving of timber can be achieved if the house roofs are inclined, scientifically designed, and covered with galvanized iron sheets.

Scarcity of forage and fodder for migratory livestock is expected to increase in alpine tundra/pastures because of a reduction in their area with climate change. The graziers will have to adapt to a lower number of livestock to match the carrying capacity of the pastures or make provision for stall feeding, or some of them may even have to give up this profession to avoid depletion of the pastures and to prevent erosion and damage to the cold conifer forests that would replace the alpine tundra biome.

(3) As mentioned before, Himalayan forests in Pakistan are under extremely heavy social pressure from the local population. The annual fuel wood drain is more than 3 times greater than the amount of wood replenished by the forests each year, and grazing intensity is 6.5 times the forage production capacity of the forests (Khattak 1992). The scarcity of resources will become more acute in the future with an increased population. The climate change may result initially in increased availability of wood because of tree dieback in cold conifer/mixed woodland biomes. Subsequently, wood scarcity would follow after the wood of these trees has been consumed. Therefore, the local people will have to be encouraged through various means, including financial assistance, to seek sources other than forests for their livelihood.

(4) At present, forestry, agriculture, horticulture, and grazing are practiced in an unplanned manner, without regard to the nature of terrain. This has resulted in widespread erosion, desertification, deforestation, loss of biodiversity, resource depletion, and environmental degradation. All efforts to reduce tree cutting and land use change on steep slopes of the mountains have so far been unsuccessful because of subsistence living conditions. Therefore, people should be allowed to continue to practice all land uses but should be encouraged to do so in a scientific manner. Further, policies and practices should be developed that reduce social pressures driving land conversion, such as increasing crop and livestock productivity and developing large tree plantations. Application of modern forestry practices to reduce harvesting damage to ecosystems, combined with the substitution of non-timber products, could reduce significantly the effect of climate change on wood availability.

(5) To avoid forest decline by climate change, consideration should be given to human actions that minimize undesirable impacts. Special attention should be given to those tree species that have poor seed dispersal, occupy ecological niches, have a small population, have a restricted range, are peripheral species, are genetically impoverished, or have important ecosystem functions (Anonymous 1996). These species should be assisted by providing natural migration corridors, but many may eventually also require assisted migration to keep up with the speed with which their habitats move with climate change and by change in land use.

\section{CONCLUSIONS AND RECOMMENDATIONS}

This study suggests that large potential forest areas in northern mountain areas of Pakistan would shift from one biome to another with future climate change. This shift would also result in an increase in the total potential coniferous forest area, especially of warm conifer forests, as well as an increase in their NPP in the coming decades. Simulated changes in the area of biomes by the model could occur along 1 of 2 pathways: (1) stock dieback followed by either natural or managed regeneration or (2) slow conversion of stock from one biome to another by migration and managed regeneration. Either or both of these pathways could occur in Pakistan. M odel-predicted ecological changes in forest area, composition, cover, and productivity should, however, be considered in the context of future socio-economic changes and the capacity of human beings to adjust and adapt to new conditions. It must be recognized that existing forests occupy a small area in Pakistan and are under heavy pressure of deforestation, land-use change, grazing, erosion, and so forth, by increasing human and cattle populations. In general, these activities are expected to worsen the forestdeficient situation in the future because of the combined influence of climate change and increased severity of socio-economic pressures on forests. As in the past, forest areas have been affected more by changes in land use than by climate change.

A number of adaptation strategies suggested in this paper to cope with climate change have been proposed at various times, occasions, and forums for conservation of forests and socio-economic development of hilly regions in the past. However, these were never fully implemented because of policy drawbacks and resource constraints. Only a scattered patchwork of forest development work was done. The result was resource depletion, environmental degradation, and increased poverty. In the final analysis, there are no special strategies to cope with climate change impacts. All that has been suggested in this paper in this regard would serve all purposes and thus constitute no-regret options. 
Acknowledgements. This study was carried out for the UNEP/GEF Project 'Country Case Study on Climate Change Impacts and Adaptation Assessment (GF/2200-96-09)' through the Ministry of Environment, Local Government and Rural Development, Government of Pakistan. Numerous persons assisted in the conduct of this study. The assistance of $\mathrm{Mr}$ Mehboob Elahi, Director General, Environment, and other officers of the Ministry of Environment, Drs Alex Haxeltine, Arne Dalfelt and Lars O. Naess of CICERO, and Mr Asif Kamal and other officers and staff of the Pakistan Forest Institute is gratefully acknowledged.

\section{LITERATURE CITED}

Amjad M, Khan N, Shah H (1996) Forestry statistics of Pakistan. Pakistan Forest Institute, Peshawar

Anonymous (1992) Forestry sector master plan: national perspective. Government of Pakistan, Planning and Development Division, Islamabad

Anonymous (1996) Climate change 1993. Impacts, adaptations and mitigation of climate change: scientific-technical analysis. Cambridge University Press, Cambridge

Champion HG, Seth SK, Khattak GM (1965) Manual of silviculture. Pakistan Forest Institute, Peshawar

Curtis PS, Drake BG, Leadley PW, Arp WJ, Whigham DF (1989) Growth and senescence in plant communities exposed to elevated $\mathrm{CO}_{2}$ concentrations on an estuarine marsh. Oecologia 78:20-26

Gates DM (1993) Climate change and its biological conse- quences. Sinaur Associates, Inc, Sunderland, MA

Haxeltine A (1996) Modelling the vegetation of the Earth. Department of Ecology, Plant Ecology, Lund University

Khan S (1988) Predicting streamflow and sediment yield for mountainous areas in Northern Pakistan. PhD dissertation, Utah State University, Logan

Khattak AK (1992) Development of a model forest management plan for the Panjul forest in Western Himalaya (Pakistan). Schriftenreihe der Forstwissenschaftlichen Fakultät der Universität München and der Bayerischen Forstlichen Versuchs- und Forschungsanstalt, M ünchen

Knudsen AJ (1994) Deforestation and entrepreneurship in NWFP, Pakistan. Chr Michelsen Institute, Fantoft 38

Miellilo J M, M cGuire AD, Kicklighter DW, Moore B, Vorosmarty CJ , Schloss AL (1993) Global climate change and terrestial primary production. Nature 363:234-240

Nielson RP (1995) A model for predicting continental scale vegetation distribution and water balance. Ecol Appl 5(2): 362-386

Norby PJ , O’Neill EG, Luxmore RJ (1986) Effects of atmospheric $\mathrm{CO}_{2}$ enrichment on growth and mineral nutrition of Quercus alba seedlings in nutrient poor soil. Plant Physiol 82:83-89

Prentice IC, Cramer W, Harrison S, Leemans R, Monserud RA, Soloman AM (1992) A global biome model based on plant physiology and dominance, soil properties and climate. J Biogeogr 19:117-134

Schickoff U (1993) Man's impact on vegetation and landscape in the Kaghan valley, Pakistan. Pakistan J For 128-148

Siddiqui KM (1997) Forestry and environment. Pakistan Forest Institute, Peshawar 